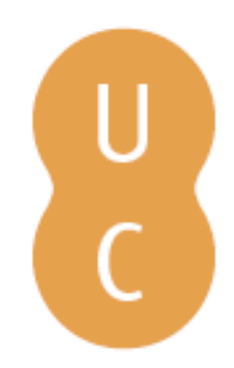

\title{
nombalina
}

\section{Bushfire fatalities and house loss in Australia: Exploring the spatial, temporal and localised context}

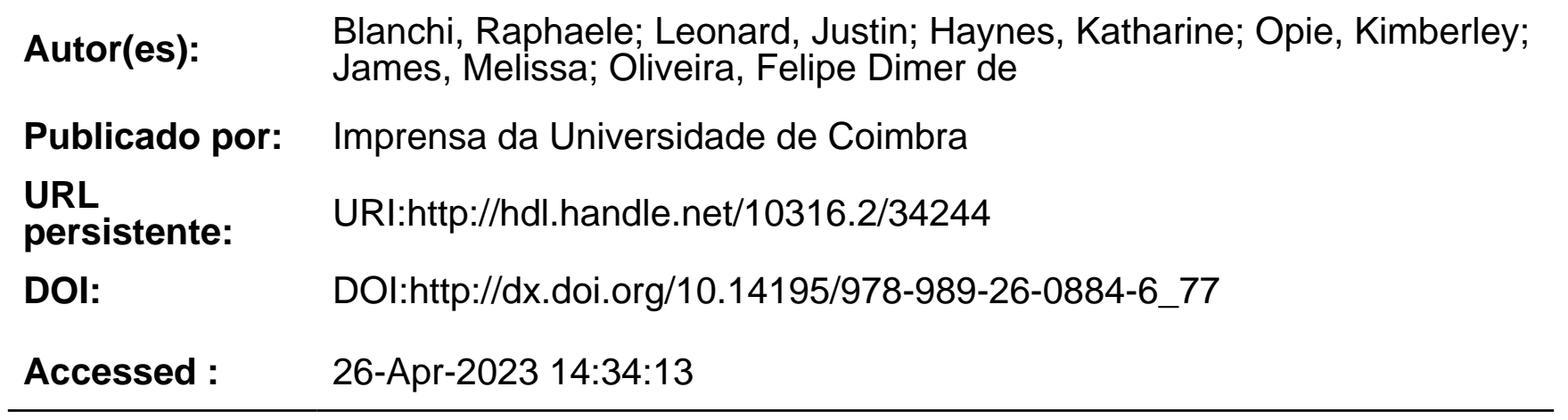

A navegação consulta e descarregamento dos títulos inseridos nas Bibliotecas Digitais UC Digitalis, UC Pombalina e UC Impactum, pressupõem a aceitação plena e sem reservas dos Termos e Condições de Uso destas Bibliotecas Digitais, disponíveis em https://digitalis.uc.pt/pt-pt/termos.

Conforme exposto nos referidos Termos e Condições de Uso, o descarregamento de títulos de acesso restrito requer uma licença válida de autorização devendo o utilizador aceder ao(s) documento(s) a partir de um endereço de IP da instituição detentora da supramencionada licença.

Ao utilizador é apenas permitido o descarregamento para uso pessoal, pelo que o emprego do(s) título(s) descarregado(s) para outro fim, designadamente comercial, carece de autorização do respetivo autor ou editor da obra.

Na medida em que todas as obras da UC Digitalis se encontram protegidas pelo Código do Direito de Autor e Direitos Conexos e demais legislação aplicável, toda a cópia, parcial ou total, deste documento, nos casos em que é legalmente admitida, deverá conter ou fazer-se acompanhar por este aviso.

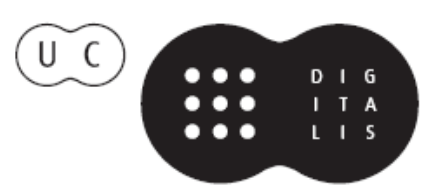




\section{ADVANCES IN}

Forest Fire

\section{RESEARCH}

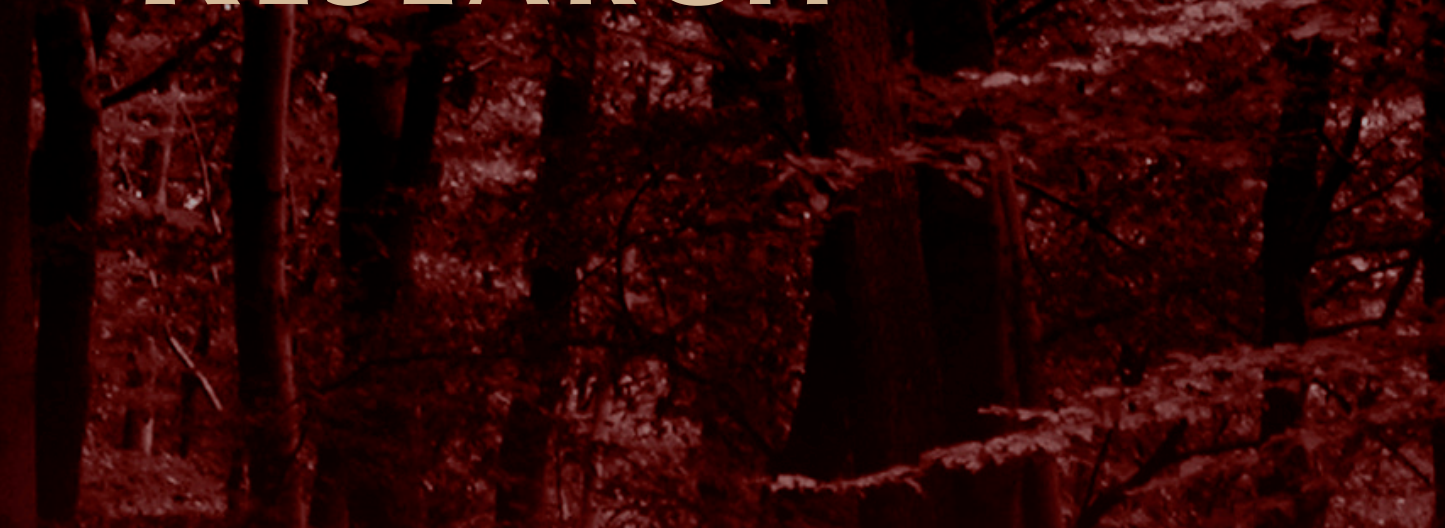

\section{DOMINGOS XAVIER VIEGAS}

\section{EDITOR}




\title{
Bushfire fatalities and house loss in Australia: Exploring the spatial, temporal and localised context
}

\author{
Dimer de Oliveira ${ }^{\mathrm{c}}$ \\ ${ }^{a}$ CSIRO Land and Water, PO Box 56, Highett, Victoria 3190, Australia. \\ Raphaele.Blanchi@csiro.au \\ ${ }^{b}$ Bushfire Cooperative Research Centre, Australia \\ ${ }^{c}$ Risk Frontiers Macquarie University
}

Raphaele Blanchi $^{\mathrm{a}, \mathrm{b}}$, Justin Leonard ${ }^{\mathrm{a}, \mathrm{b}}$, Katharine Haynes ${ }^{\mathrm{b}, \mathrm{c}}$, Kimberley Opie ${ }^{\mathrm{a}}$, Melissa James ${ }^{\mathrm{a}}$, Felipe

\begin{abstract}
:
This paper examined the spatial, temporal and localised context of bushfire fatalities and house loss in Australia. The analysis focused principally on understanding the strength of correlations between location where fatal exposure occurred, fire weather conditions (using the McArthur Forest Fire Danger Index (FFDI) and its individual components), proximity to fuel, proximity to other objects (houses and/or vehicles) and fatality activity and decision making leading up to the death.

The analysis is based on a dataset containing bushfire related life loss and house loss in Australia over the past 110 years (1901-2011). Over this time period 260 bushfires have been associated with a total of 825 known civilian (733) and firefighter fatalities (92), and 8778 houses destroyed. The analysis included spatial, temporal and localised context in which the fatalities have occurred.

The analysis demonstrated that:

- The losses are dominated by major events that have occurred under very severe weather conditions

- The location of fatal exposure provides a useful context to better understand the specific level of shelter a person had when they died with $58 \%$ occurring out in the open, $28 \%$ occurring inside structures and $8 \%$ in vehicles.

- Male and female civilian fatalities within structures were evenly represented, while male fatalities out in the open were approximately 3 times greater than female fatalities out in the open (mainly in earlier years)

- $41 \%$ of fatalities within structure occurred in rooms with reduced visibility to the outside

- Fatalities within structures represent over $75 \%$ of all fatalities under very severe conditions (weather conditions exceeding an FFDI value of 100). These are associated with people dying while attempting to shelter mainly in their place of residence. Conversely lower values of FFDI are associated with people who are caught outside while defending their property.

- Over $60 \%$ of fatalities occurred within $100 \mathrm{~m}$ of a residence

- $80 \%$ of all fatalities and $60 \%$ of the house loss occurred within $30 \mathrm{~m}$ of the forest.
\end{abstract}

Keywords: Wildland fire, Fatalities, WUI, House loss, Risk

\section{Introduction}

In Australia the studies of community safety at the urban interface were mainly based on post bushfire surveys and subsequent analysis to better understand the mechanisms of bushfire attack at the urban interface. The important points of consideration in those studies were on the building design, the immediate landscape, the type of urban interface and human activity and how they significantly influence the risk of loss (e.g. Barrow, 1945; Raphaele Blanchi \& Leonard, 2008; Leonard \& McArthur, 1999; Ramsay et al., 1987).

Some studies have been performed on the behaviour of civilian fatalities during bushfires (e.g. Handmer \& Haynes, 2008; Haynes et al., 2010; O’Neill \& Handmer, 2012; Tibbits, Blanchi, \& Gill, 2006). While these studies on civilian fatalities have mainly focused on the behaviour of the victims 
and are mainly conducted within the context of the 'Stay or Go' policy', they have not included the spatial and environmental circumstances of their death.

Other studies have investigated the circumstances of firefighter fatalities involving entrapment and burnovers (Butler \& Cohen, 1998; Cheney et al., 2001; Viegas et al., 2008). Meanwhile some studies have focused on the influence of environmental circumstances on house loss for individual events or multiple events in Australia (e.g. Ahern \& Chladil, 1999; Blanchi et al., 2010; Butler \& Cohen, 1998; Gibbons et al., 2012; Harris et al., 2012; Newnham et al., 2012) and the US (e.g. Cohen, 2000; Menakis et al., 2003; Syphard et al., 2012).

This study examined the environmental circumstances of bushfire fatalities and house loss in Australia over the last 110 years, using a specific data set that included spatial, temporal and localised context (Life Loss database). The results presented in this paper are related to the relationship between fatal exposure location, house loss, weather conditions, and proximity to fuel and additional analysis components are presented in Blanchi et al. (2014).

\section{Methods and data}

The database (Life Loss database) developed for the analysis is a spatial dataset of bushfire related fatalities and related losses (such as house loss) and circumstances, in Australia over the past 110 years (1901-2011). It also captures the circumstances leading up to the fatal exposure such as weather context using the McArthur Forest Fire Danger Index (FFDI) ( McArthur, A.G., 1978; McArthur, 1967), fire severity, distance to forest, fatality activity and decision making (Blanchi et al., 2014; Blanchi et al., 2012).

A number of different data sources were accessed in order to assemble the Life Loss database. This includes coronial inquest records, royal commission reports, journal papers, books, post bushfire study reports, fire agency review documents of major fires, newspaper articles and collated datasets on past bushfire fatalities (Blanchi et al., 2012; Haynes et al., 2010).

Different types of data have been compiled in the dataset: quantitative variables (e.g. weather information), and categorisation variables (e.g. location of fatality). Some information was categorised to facilitate spatial and statistical analysis. The detail of the data collection is presented in Blanchi et al. $(2012,2014)$.

The Life Loss database contains 825 fatalities, 733 are civilian and 92 are listed as firefighters. Of the fatalities contained in the database 741 were directly related to the fire itself (674 civilians and 67 firefighters). Fifty fatalities were indirectly related to a fire event and the specific cause of death for 34 persons was unknown or unclear.

The data was grouped into three time periods: for the entire time period of data, pre 1965, and post 1965. This segregation of data also happens to be useful in distinguishing some patterns over the years, and provided an opportunity to compare demographic context relating to social behaviour and prevalence of technologies such as automobiles.

The analysis examined the:

- demographics

- distribution of fatalities and house loss in time

\footnotetext{
${ }^{1}$ Referred to as the 'Stay or Go' policy, the policy recommended that either actively defending a well-prepared home or evacuating/relocating well in advance of a fire threat are the best survival options during a bushfire. formed the basis of the Bushfire and Community Safety Position developed by the Australasian Fire and Emergency Service Authorities Council (AFAC) before the 2009 Victorian fires AFAC (2005) Position Paper on Bushfires and Community Safety. AFAC Limited, Victoria, Australia. This position was translated into the prepare, stay and defend or leave early policy in most jurisdictions.
} 
- location of fatal exposure

- importance of weather conditions on loss

- influence of distance to forest on loss

\section{Results and discussion}

\subsection{Demographics}

The gender and age distribution of all fatalities (civilians and firefighters) was studied to help inform specific trends relating to assumed behaviours or activities. Data was grouped into three time periods; for the entire time period of data, pre 1965, and post 1965. The gender role could also demonstrate an evolution of behaviour in the different roles of men and women over the century.

In summary, in earlier fires a higher proportion of the lives claimed were of young children, whereas more recent fires have claimed the lives of a higher proportion of older people. The distinction between civilians (further broken into gender) and firefighters is shown in Figure 1 for the two periods considered and for all known genders ( 29 unknown). This figure highlights the significant increase of female civilian fatalities in recent fires.

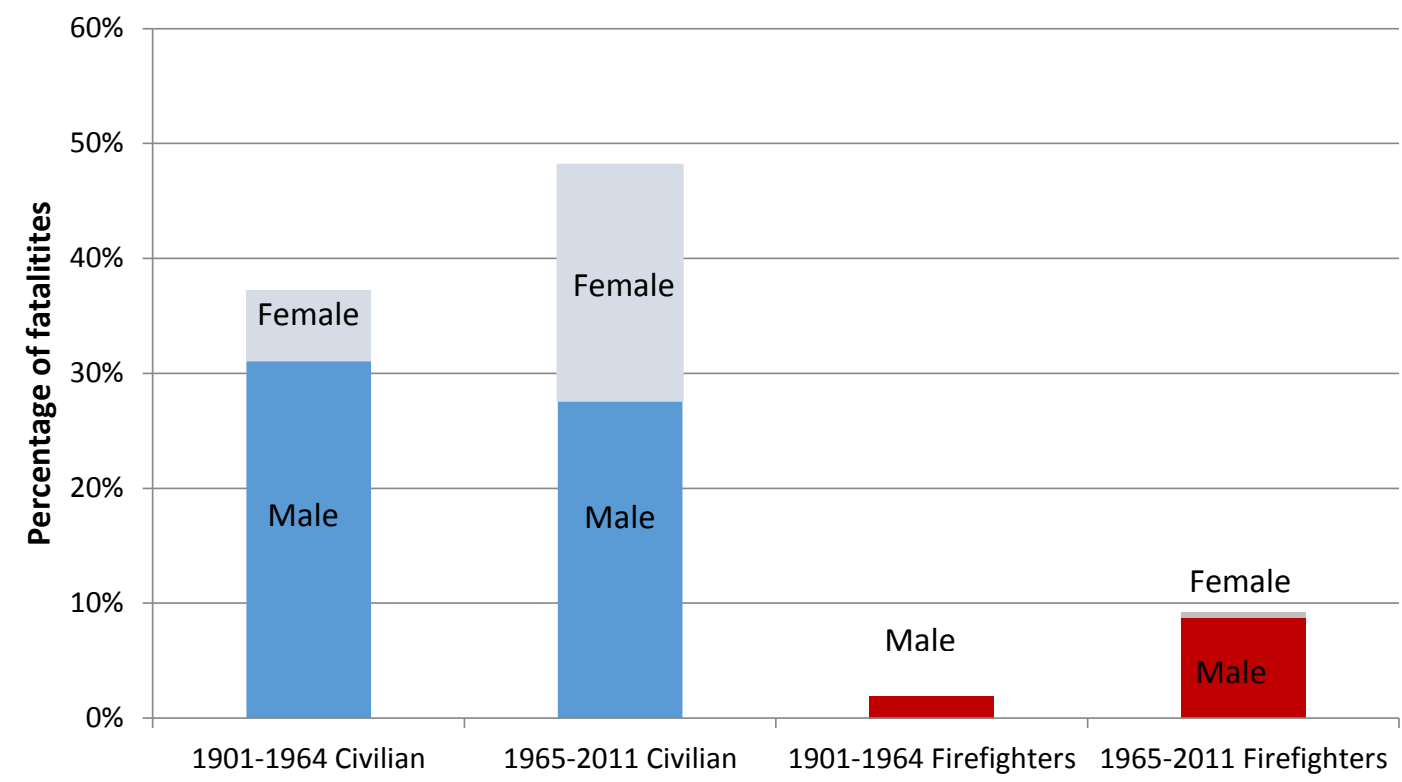

Figure 1. Number of fatalities by gender between the period 1901-1964 and the period 1965-2011 (distinction between civilian and firefighters)

\subsection{Distribution of fatalities and house loss in time}

The number of fatalities and house loss is dominated by a few major events resulting in large number of the fatalities and house destruction (Figure 2 and Figure 3). This is in accordance with the finding of Haynes et al. (2010) and Blanchi et al. (2010) which has shown that the losses per event and spatial distribution of loss are strongly influenced by fire weather severity. 


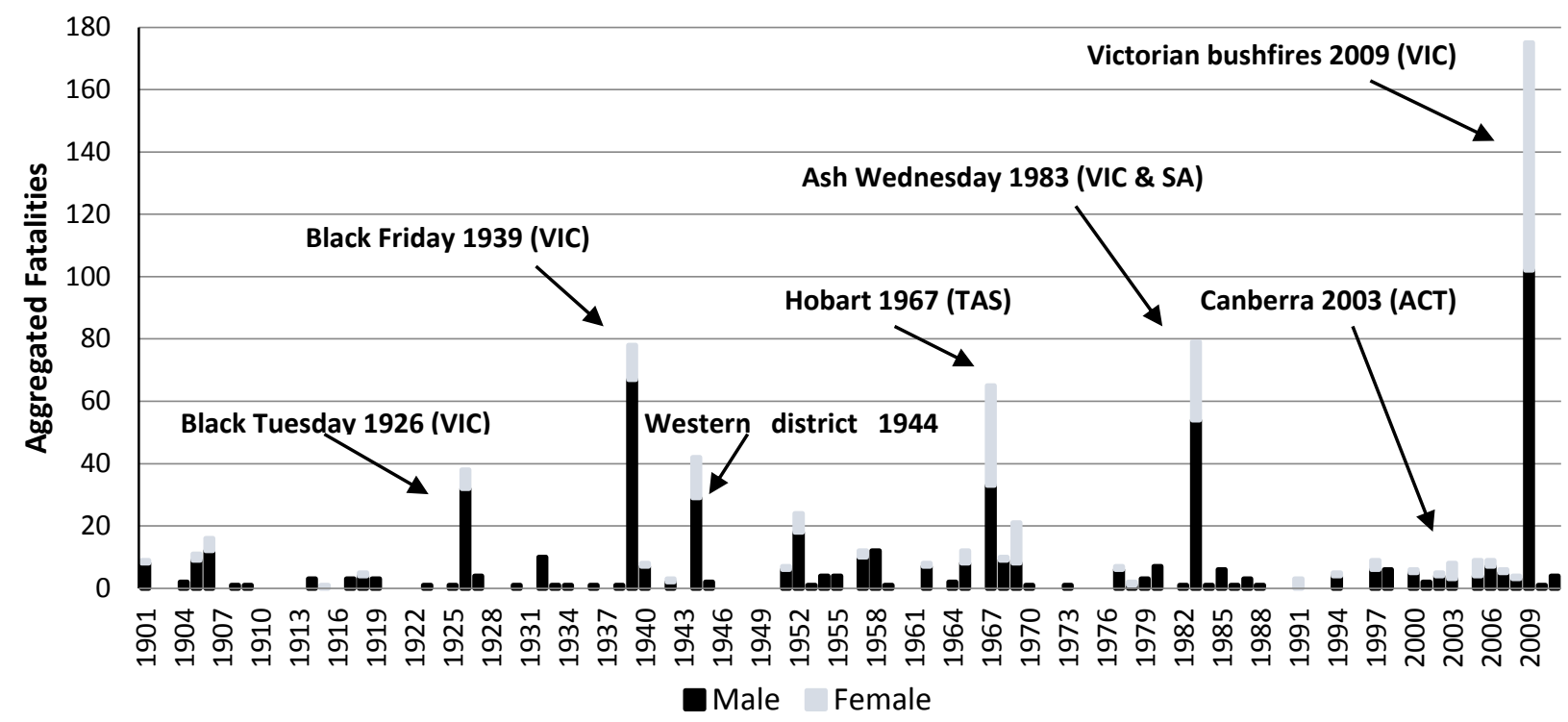

Figure 2. Distribution of number of fatalities over the time period (1901-2011) including civilian and firefighters in Australia

While the graph shows no consistent trend there is an increase in the loss per year rate when comparing the two time period categories (1901-1964 and 1965-2011). For the period 1901-1964, 5.1 civilian fatalities occurred per year and for 1965-2011, 8.6 fatalities occurred per year.

The number of houses lost for the period 1901-2011 shows a similar pattern (see Figure 3 ) and is dominated by the same iconic events (Blanchi et al 2010). There is a more noticeable bias toward losses in more recent years. This is in part due to the lack of house loss data in the 1901-1926 time period and also due to better record of house losses in recent years and an increase of population and houses in fire prone area. Keeping this in mind the 1901-1964 house loss average is 44 per year and the 1965-2011 average is 168 per year.

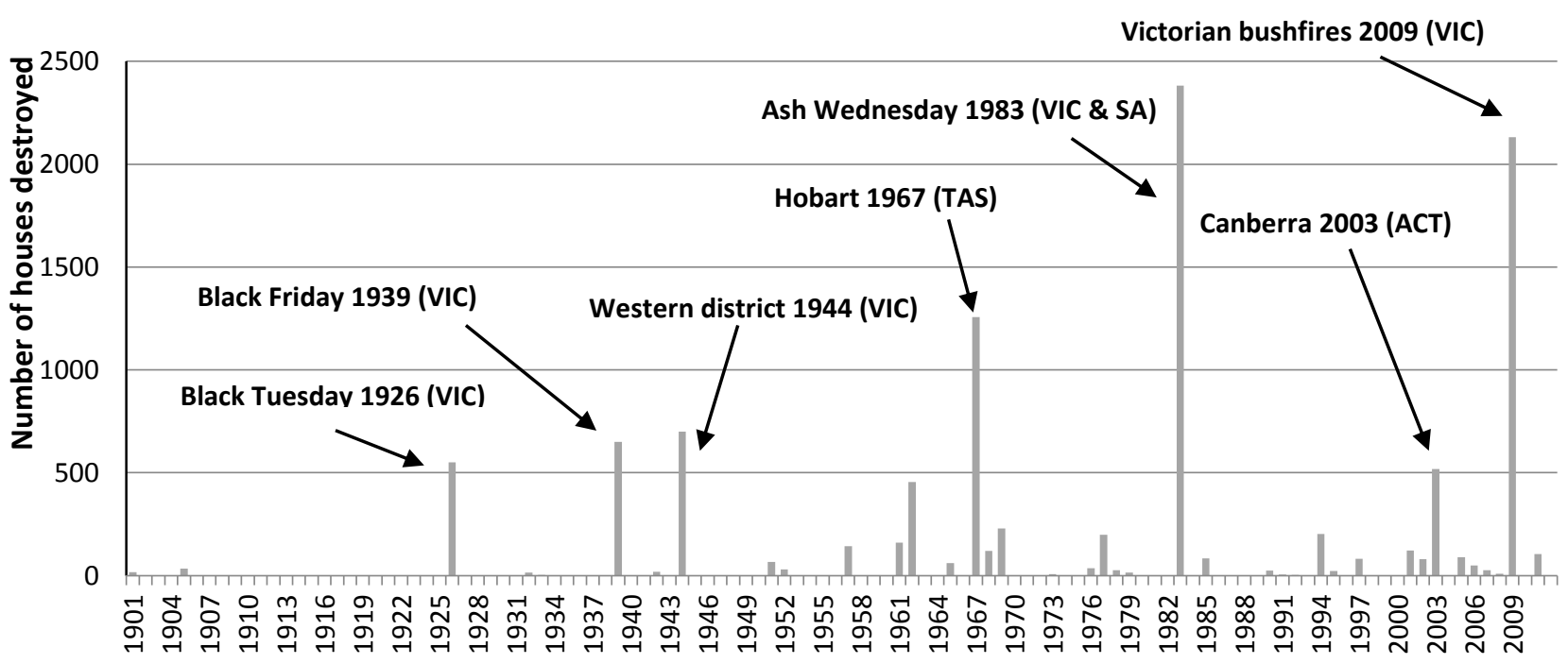

Figure 3. Distribution of number of house burnt (destroyed) over the time period (1901-2011) in Australia

Figure 4 profiles the time of fatal exposure (when known) for both firefighters (44) and civilians (397). This figure shows a clustering of civilian fatalities from $10 \mathrm{am}$ through to $11 \mathrm{pm}$ with one peak at $10 \mathrm{am}$. 
This peak is mainly due to a single loss event, where 17 motorists lost their lives on the Princes Highway between 10am and $11 \mathrm{am}$ in the Victorian Lara fire in 1969. Without this anomaly, the civilian fatalities exhibit a normal distribution around $6 \mathrm{pm}$. Firefighter fatalities have a similar fatality time distribution to civilians, with a peak at $3 \mathrm{pm}$ and $9 \mathrm{pm}$ (which correspond to the Ash Wednesday fire where 12 firefighters died during a burnover).

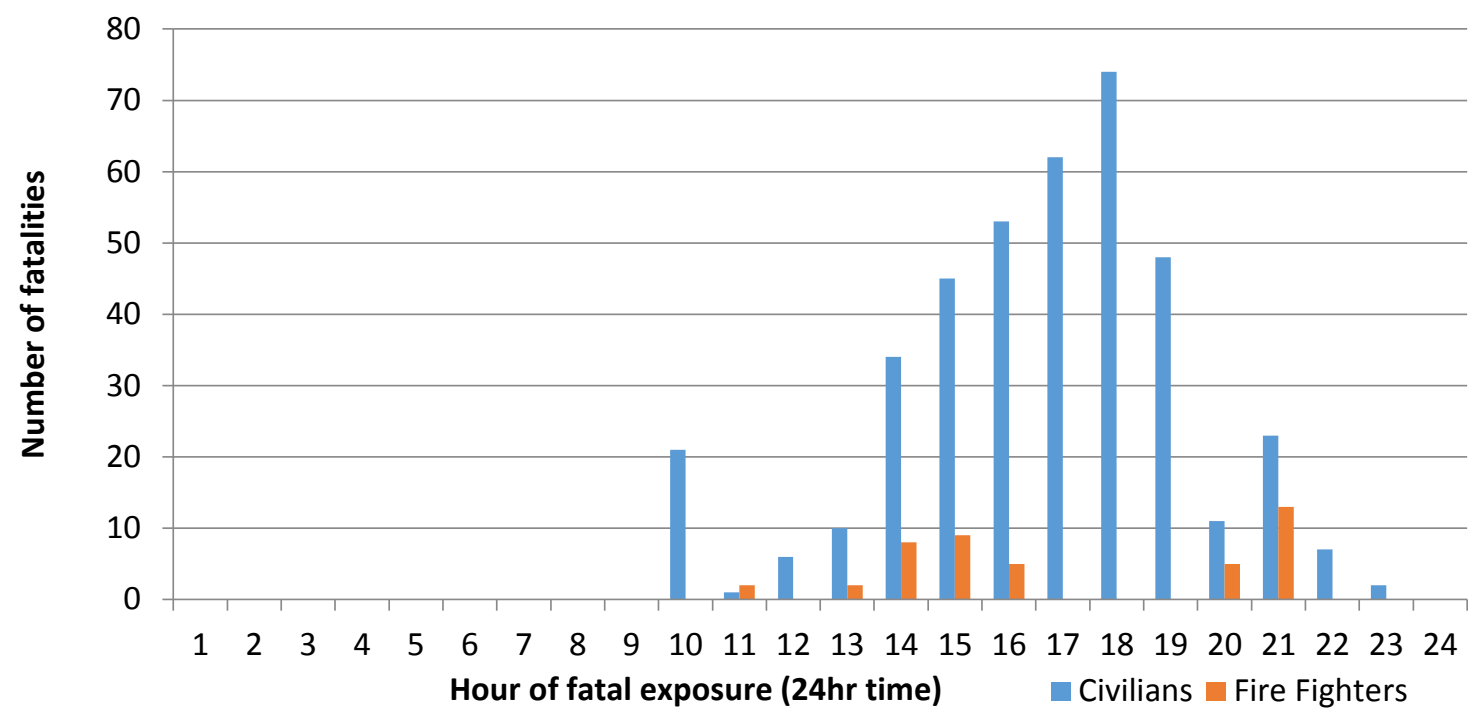

Figure 4. Hour of civilian and firefighter fatal exposure for all directly related deaths

\subsection{Location of fatal exposure}

The location of fatalities was categorised into 'In structure', 'In vehicle' \& 'Open air' to better understand the specific level of shelter a person had when they died. Table 1 summarises the location categories of fatal exposure for the three time periods (1901-2011; 1901-1964; and 1965-2011) with $58 \%$ occurring out in the open, $28 \%$ occurring inside structures and $8 \%$ in vehicles.

A significantly greater proportion of fatalities occurred inside structures or inside vehicles in recent fires, compared to earlier fires. The higher proportion of fatalities inside vehicles in the time period 1965-2011 is explained by higher prevalence of cars and their use during this period. This summary also highlights that in earlier fires a significantly greater proportion of fatalities occurred in the open air, compared to more recent fires.

Male and female civilian fatalities within structures were evenly represented, while male fatalities out in the open were approximately 3 times greater, particularly earlier in the century. This is possibly related to job profiles that involve remote location work such as timber felling where shelter is not easily found or farmers attempting to save livestock (Blanchi et al., 2012).

Firefighter fatalities occurred in open air, in fire fighting vehicle burn-over incidents or from falling trees. Sheltering within a structure is a relatively rare and often unavailable strategy for firefighters.

Table 1. Fatal exposure location categories over the three time periods (civilian)

\begin{tabular}{|c|c|c|c|}
\hline & 1901-1964 & 1965-2011 & 1901-2011 (total) \\
\hline Inside structure & $21(7.1 \%)$ & $167(44.4 \%)$ & $188(27.9 \%)$ \\
\hline Inside vehicle & $11(3.7 \%)$ & $45(12.0 \%)$ & $56(8.3 \%)$ \\
\hline Open air & $232(77.8 \%)$ & $158(42.0 \%)$ & $390(57.8 \%)$ \\
\hline Unknown & $34(11.4 \%)$ & $6(1.6 \%)$ & $40(5.9 \%)$ \\
\hline Total & $298(100 \%)$ & $376(100 \%)$ & $674(100 \%)$ \\
\hline
\end{tabular}


The distance of a fatality to their residence can help qualify the prevalence of behaviours in relation to last minute evacuation or alternative shelter and defence strategies. A sample set of 116 fatalities from the Life Loss database for which residential address and fatal exposure locations were both accurately known was analysed. This sample set included 79 fatalities that occurred in open air, 18 that occurred inside a vehicle and 19 inside a structure (other than their residence, e.g. a neighbouring house, bunker etc). These cases have been plotted as cumulative graph in Figure 5.

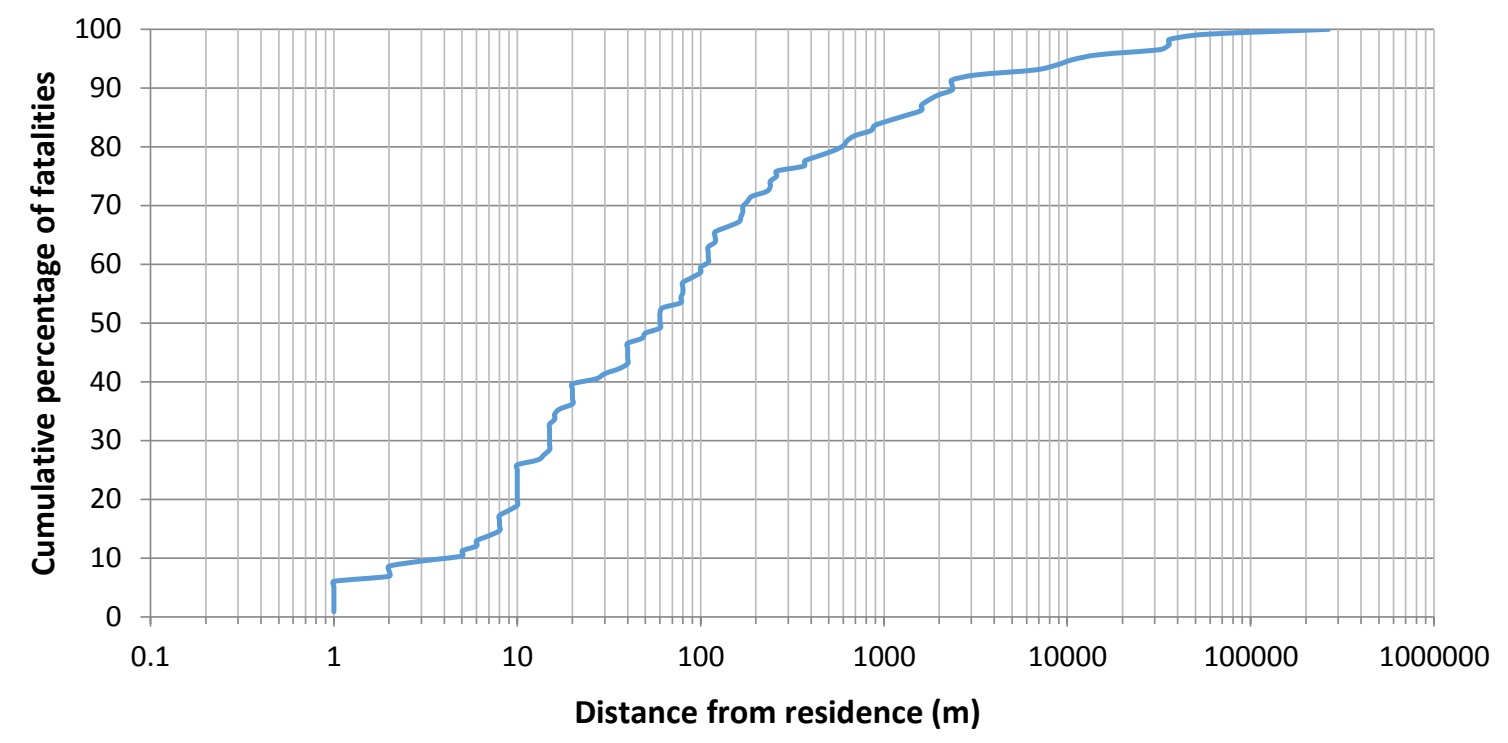

Figure 5. Distance between residential address and fatal exposure location (civilian)

Table 2 shows a close association with the place of residence, with $61 \%$ of fatalities occurring within $100 \mathrm{~m}$ of their location of residence and $84 \%$ occurring within $1 \mathrm{~km}$. Analysis of the locations of residence of the deceased showed that 10 houses were not damaged and were not used as a shelter, 89 houses were completely destroyed and of these 20 houses were used as a place of refuge during the event. The main activity of the fatalities considered in the analyses was late evacuation (48.3\%), followed by saving livestock, livelihood or defending wider property outside (20.7\%), and people sheltering as a group (11.2\%).

For the fatalities that occurred inside structures it is useful to understand the location within the structure in which the fatal exposure occurred, as this will help to understand the behaviour adopted and the modes in which the house may have lost its tenability. Table 2 shows the location of fatality inside residential structures.

Table 2. Known fatality locations inside residential structures

\begin{tabular}{lll}
\hline Location inside structure & Number of fatalities & Percentage of known \\
\hline Bathroom & 36 & $33 \%$ \\
Kitchen & 25 & $23 \%$ \\
Bedroom & 17 & $16 \%$ \\
Study & 10 & $9 \%$ \\
Enclosure under house & 9 & $8 \%$ \\
Entrance & 5 & $5 \%$ \\
Lounge & 4 & $4 \%$ \\
Laundry & 3 & $3 \%$ \\
Total & $\mathbf{1 0 9}$ & $\mathbf{1 0 0 \%}$ \\
\hline
\end{tabular}


Of these cases $33 \%$ of the fatalities occurred in bathrooms which typically have no clear visual cues to outside conditions. All other cases either involved an opportunity to monitor outside conditions or be adjacent to an exit to facilitate egress when the house approaches untenable conditions. Eight percent of cases were in either the entrance or laundry: both typically are adjacent to an exit door providing an option to egress if conditions allowed.

Fifty-eight percent involved fatalities in the bathroom, bedroom or study which all typically have only one point of exit to the rest of the house. Twenty-seven percent of cases involved kitchens and lounge areas which usually have opportunities for viewing outside conditions and multiple options to progress through the house towards an exit if it is recognised that the house is losing tenability.

In summary, for $59 \%$ of the fatalities there was the opportunity to effectively monitor both the internal and external conditions and make decision to move towards an exit as the house lost tenability. So either people were not aware of this strategy (or the need to leave) or the houses lost tenability at a rate in which safe passage from these locations to an exit door was not possible. This raises several questions in relation to egress, sheltering and the rate of loss of tenability of houses. Also to consider are the air toxic emitted and exposure concentrations inhaled by residents both indoors and outdoors (Reisen, Blanchi, \& Tibbits, 2006).

\subsection{Weather conditions and loss}

The influence of meteorological conditions on loss has been shown in previous studies (Raphaele Blanchi et al., 2010; Bradstock, Gill, Kenny, \& Scott, 1998). The weather conditions (using forest fire danger index) and aggregated fatalities and house loss by fire event is studied.

The FFDI is categorised according to the existing national danger rating scheme ${ }^{1}$ :

- 0-11: low - moderate

- 12-24: high

- 25-49: very high

- 50-74: severe

- 75-100: extreme

- >100: catastrophic (Code Red in Victoria)

The cumulative percentile of both house loss and fatalities is related to the $3 \mathrm{pm}$ FFDI on the day of the loss (see Figure 6). Less than 3\% of house losses and fatalities occurred when the FFDI was less than 49 (moderate to very high), roughly 7\% occurred when the FFDI was between 25 and 50, and $25 \%$ of either house or life loss occurred when the FFDI was below 74 . Over $60 \%$ of all fatalities and $75 \%$ of all house loss in Australia has occurred on days where the 3pm FFDI exceed 100.

Three large events dominate the results in the over FFDI 100 category: the Black Tuesday fires (7 February 1967) in Hobart, the Ash Wednesday fires (16 February 1983) in Victoria and South Australia, and the Victorian bushfires (7 February 2009).

${ }^{1}$ http://www.cfa.vic.gov.au/warnings-restrictions/about-fire-danger-ratings/ (accessed 15/06/2014) 


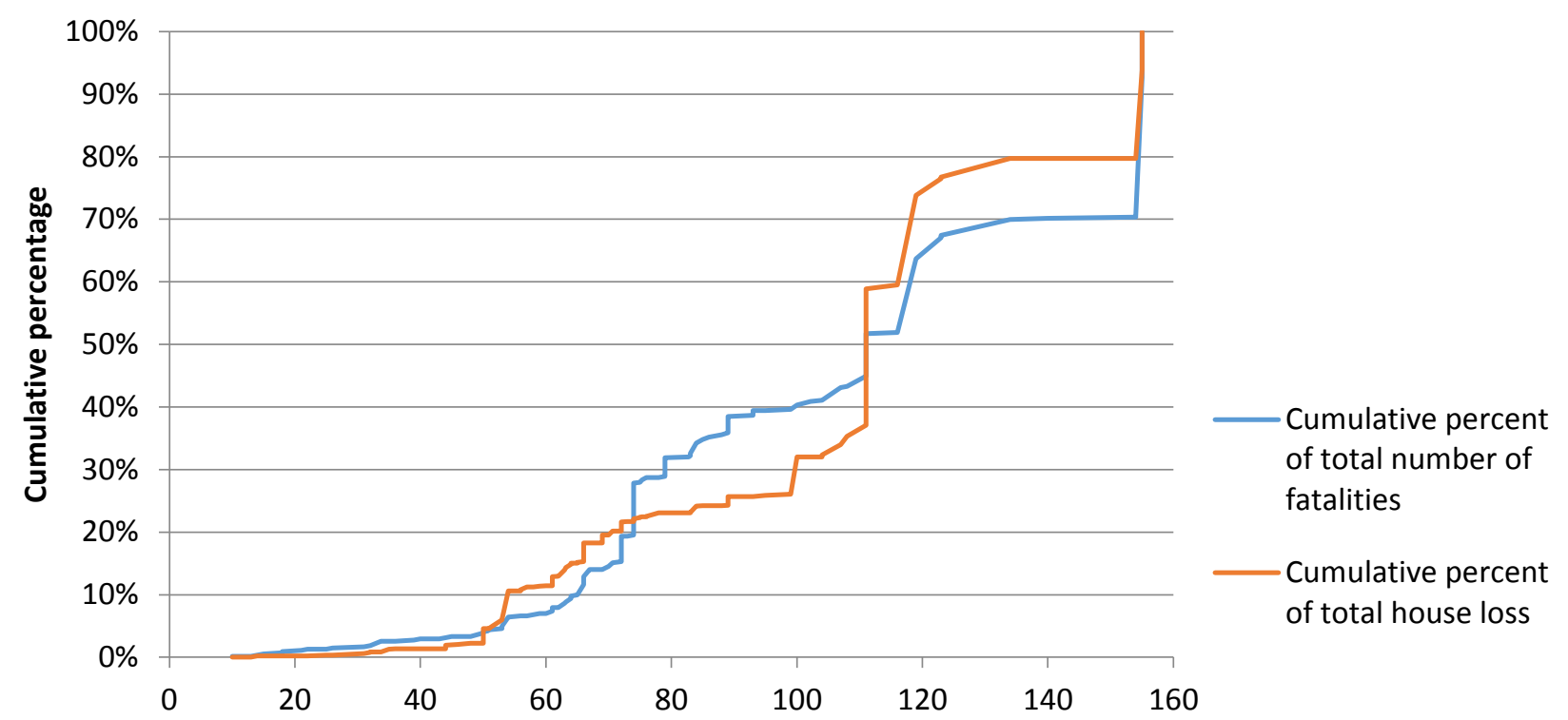

Forest Fire Danger Index

Figure 6. Cumulative percent of total number of fatalities and house loss versus FFDI

The location category of fatal exposure was compared to FFDI classes in Figure 7. There is an expected link with the location of fatal exposure and fire weather severity owing to the different vulnerabilities of each location context. The most noticeable result is the high prevalence of deaths inside structure for an FFDI of 100 plus category (fire danger rating 'catastrophic'). This may be due to a tendency to seek shelter from both the severe weather and the fire under such intense conditions. It also indicates that houses are likely to lose tenability more rapidly under these conditions and cause entrapment. At lower levels of FFDI (0-74) civilians are caught outside as the predominant loss location category.

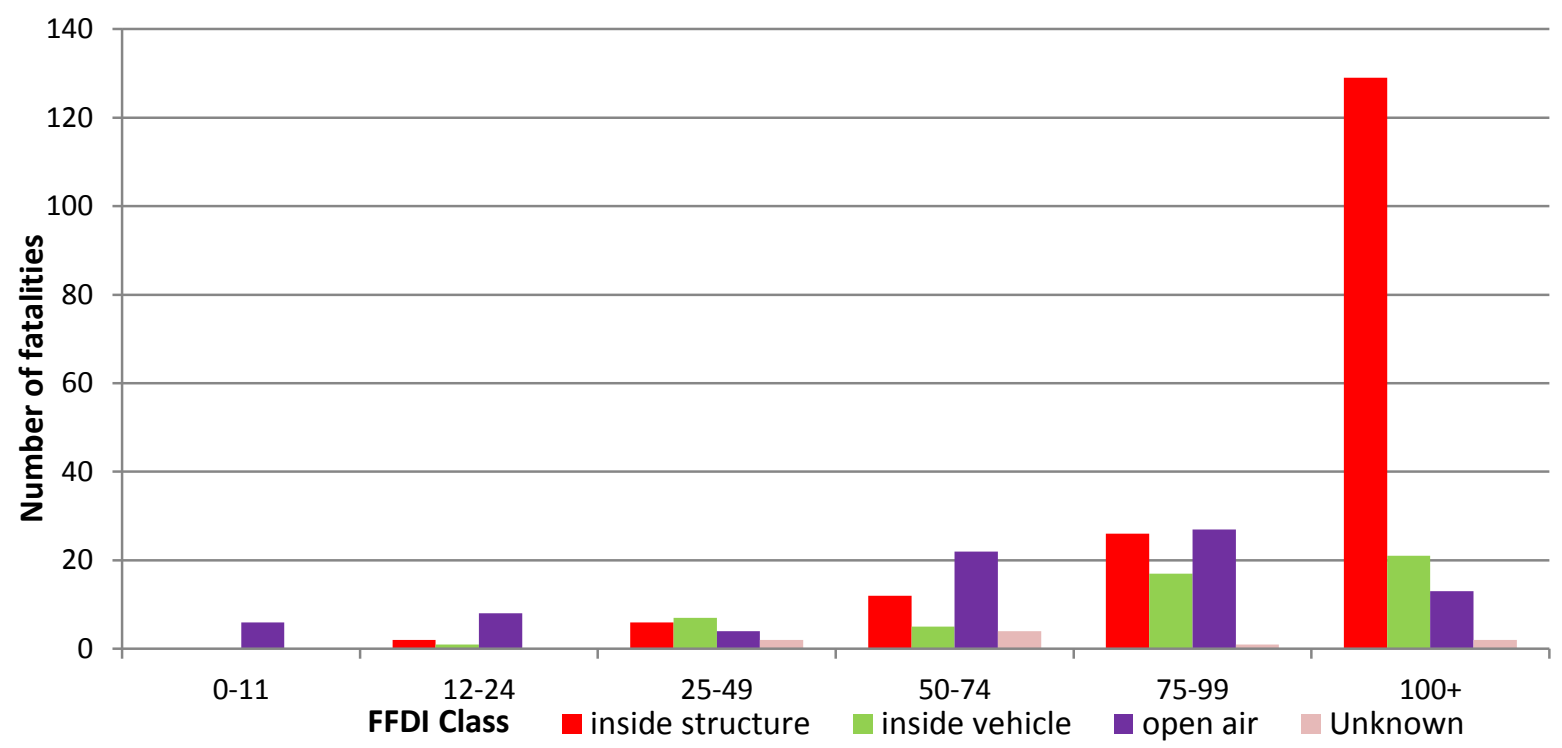

Figure 7. FFDI at 3pm and location of fatality (Blanchi et al. 2014) 


\subsection{Distance to forest}

The separation between bushfire fuels and the fatality is an important risk assessment metric to classify likely exposure levels on the person, vehicle or structure. For the spatial analysis, the forest layer of the closest preceding year to the fire was used to determine the distance to forest. It is assumed that the layer which coincides with the year of the fire has a high likelihood of the fire scar affecting extent of forest for that year.

Of particular interest is the observation that over $50 \%$ of all fatalities occurred less than $10 \mathrm{~m}$ from the forest, $78 \%$ in less than $30 \mathrm{~m}$ and $85 \%$ in less than $100 \mathrm{~m}$. This provides a strong qualification of the possible influence of forest proximity as a factor in defining exposure resulting in fatal outcomes (Blanchi et al. 2014).

Comparing these percentages with the broader dataset of house loss as a function of distance to forest demonstrates that house loss involving fatal exposure are far more dominant in the $0-30 \mathrm{~m}$ from forest regions. Compared to house losses not involving fatalities, less than $60 \%$ of all house losses occurred less than 30m from the forest (Newnham et al., 2012). It is to be noted that $30 \mathrm{~m}$ is a distinctive threshold for direct radiant heat ignition of structures identified by Cohen (Cohen, 2008).

\section{Conclusion}

The database developed integrate information on losses including details of fire weather severity (using the McArthur Forest Fire Danger Index (FFDI) and its individual components), fire behaviour, proximity to forest, incident circumstances, fatality details, activities and the location of objects and structures related to the fatality. This paper focused on a subset of the analysis developed in the study, more information is available in Blanchi et al. $(2012,2014)$.

The study provided a better understanding of the circumstances of losses in particular the importance of fire weather conditions and proximity to fuel hazard in setting the context for loss. The findings of the study can be directly integrated in policies and community education initiatives for bushfire related life risk reduction.

\section{Acknowledgement}

This research was funded by the Australian Attorney General's Department (via Bushfire CRC). We gratefully acknowledge all the people who contributed to this research from various governmental and research organisations: The Australasian Fire and Emergency Service Authorities Council, Department of Environment and Conservation, Department of Fire and Emergency Services formerly the Fire and Emergency Services Authority of WA, New South Wales Rural Fire Service, Country Fire Authority Victoria, Tasmanian Fire Service, Department of Sustainable Ecosystem, ACT Emergency Services, Queensland fire and rescue service; Coroners Court of Victoria, New South Wales, and South Australia, Public record from Victoria, New South Wales and South Australia; Department of Climate Change and Energy Efficiency, Lucinda Coates and Robin Van den Honert (Risk Frontiers), Chris Lucas (BOM), Joshua Whittaker and John Handmer (RMIT).

We would like to thank Fabienne Reisen, Glenn Newnham and the anonymous reviewer for their helpful reviews, suggestions and comments.

\section{References}

Ahern, A., \& Chladil, M. (1999). How far do bushfires penetrate urban areas? Proc. Australian Disaster Conf. 1999, Disaster Prevention for the 21st Century. Canberra: Emergency Management Australia. Barrow, G. J. (1945). survey of houses affected in the Beaumaris fire, January 14, 1944. Journal of the Council for Scientific and Industrial Research, 18(1). 
Blanchi, R., \& Leonard, J. (2008). Property safety: judging structural safety. In J. Handmer \& K. Haynes (Eds.), Community Bushfire Safety (pp. 77-85).

Blanchi, R., Leonard, J., Haynes, K., Opie, K., James, M., Kilinc, M., ... Van den Hornet, R. (2012). Life and house loss database description and analysis - Final report (p. 92p). Melbourne: CSIRO, Bushfire CRC report to the Attorney-General's Department. CSIRO EP-129645.

Blanchi, R., Leonard, J., Haynes, K., Opie, K., James, M., \& Oliveira, F. (2014). Environmental circumstances surrounding bushfire fatalities in Australia 1901-2011. Environmental Science and Policy, 37, 192-203.

Blanchi, R., Lucas, C., Leonard, J., \& Finkele, K. (2010). Meteorological conditions and wildfirerelated houseloss in Australia. International Journal of Wildland Fire, 19(7), 914-926.

Bradstock, R. A., Gill, A. M., Kenny, B. J., \& Scott, J. (1998). Bushfire risk at the urban interface estimated from historical weather records: consequences for the use of prescribed fire in the Sydney region of south-eastern Australia. Journal of Environmental Management, 52(3), 259-271. Retrieved from <Go to ISI $>$ ://000074067700005

Butler, B., \& Cohen, J. (1998). Firefighter safety zones: a theoretical model based on radiative heating. International Journal of Wildland Fire, 8(2), 73-77.

Cheney, P., Gould, J., \& McCaw, L. (2001). The dead-man zone - a neglected area of firefighter safety. Australian Forestry, 64(1), 45-50. Retrieved from <Go to ISI >://CABI:20013072244

Cohen, J. D. (2000). Preventing disaster. Journal of Forestry., 98(3), 15. Retrieved from http://proquest.umi.com/pqdweb?did=55322153\&sid=1\&Fmt=1\&clientId=82754\&RQT=309\&V Name $=$ PQD

Cohen, J. D. (2008). The wildland-urban interface fire problem. A consequence of the fire exclusion paradigm. Forest History Today, (Fall 2008, 20-26.

Gibbons, P., van Bommel, L., Gill, A. M., Cary, G. J., Driscoll, D. A., Bradstock, R. A., ... Lindenmayer, D. B. (2012). Land Management Practices Associated with House Loss in Wildfires. PLoS ONE, 7(1), e29212. Retrieved from http://dx.doi.org/10.1371/journal.pone.0029212

Handmer, J. W., \& Haynes, K. (2008). Community bushfire safety (p. xv, 205 p.). Collingwood, Vic.: CSIRO Publishing. Retrieved from http://csiro.aquabrowser.com/?itemid=|library/m/CSIROvoyager|380524

Harris, S., Anderson, W., Kilinc, M., \& Fogarty, L. (2012). The relationship between fire behaviour measures and community loss: an exploratory analysis for developing a bushfire severity scale. Natural Hazards, 63(2), 391-415. doi:DOI 10.1007/s11069-012-0156-y

Haynes, K., Handmer, J., McAneney, J., Tibbits, A., \& Coates, L. (2010). Australian bushfire fatalities 1900-2008: exploring trends in relation to the "Prepare, stay and defend or leave early" policy. Environmental Science \& Policy, 13(3), 185-194. Retrieved from http://www.sciencedirect.com/science/article/B6VP6-4YNT93S2/2/1345112f4c3c3a1815fffac6277a739e

Leonard, J., \& McArthur, N. A. (1999). A history of research into building performance in Australian bushfires. Proc. Bushfire 99: Australian Bushfire Conference. Albury, 7-9 July 1999.

Luke McArthur, A.G., R. H. (1978). Bushfires in Australia. Reprinted with corrections 1986. Canberra Publishing and Printing Co.

McArthur, A. G. (1967). Fire behaviour in eucalypt forests. Leaflet No. 107. Comm. of Australia For. \& Timber Bur.

Menakis, J. P., Cohen, J. D., \& Bradshaw, L. S. (2003). Mapping wildland fire risk to flammable structures for the conterminous United States. (K. E. M. Galley, R. C. Klinger, \& N. G. Sugihara, Eds.)Fire Conference 2000: The First National Congress on Fire Ecology, Prevention and Mangement. Tallahassee, FL: Timber Research station.

Newnham, G. J., Siggins, A. S., Blanchi, R. M., Culvenor, D. S., Leonard, J. E., \& Mashford, J. S. (2012). Exploiting three dimensional vegetation structure to map wildland extent. Remote Sensing of Environment, 123, 155-162. doi:10.1016/j.rse.2012.02.026 
O’Neill, S. J., \& Handmer, J. (2012). Responding to bushfire risk: the need for transformative adaptation. Environmental Research Letters, 7(1). doi:Artn 014018 Doi 10.1088/17489326/7/1/014018

Ramsay McArthur, N.A. Dowling, V.P., G. C. (1987). Preliminary results from an examination of house survival in the 16 February 1983 bushfires in Australia. Fire and Materials, 11, 49-51.

Reisen, F., Blanchi, R., \& Tibbits, A. (2006). Potential health impacts to residents from smoke exposure during bushfires. (D. X. Viegas, Ed.)V International Conference on Forest Fire Research, 27-30 November 2006. Figueira da Foz, Portugal.

Syphard, A. D., Keeley, J. E., Massada, A. B., Brennan, T. J., \& Radeloff, V. C. (2012). Housing arrangement and location determine the likelihood of housing loss due to wildfire. PLoS ONE, 7(3). Retrieved from http://www.scopus.com/inward/record.url?eid=2-s2.084859025192\&partnerID=40\&md5=9e97acec962c6cd7e196d8e133948af9

Tibbits, A., Blanchi, R., \& Gill, A. M. (2006). A Resident's experiences of the 2003 Canberra bushfire. Australasian Bushfire Conference. Brisbane.

Viegas, D. X., Stipanicev, D., Ribeiro, L., Pita, L. P., \& Rossa, C. (2008). The Kornati fire accident eruptive fire in relatively low fuel load herbaceous fuel conditions. Modelling, Monitoring and Management of Forest Fires, 119, 365-375. Retrieved from <Go to ISI>://000260498200036 